\title{
Investigating Variation Orders Causes in Iraqi Building Construction Projects
}

\author{
Hassan Kamal Alhilli ${ }^{1, a^{*}}$ and Sedki I. Rezoqi ${ }^{2, b}$ \\ ${ }^{1}$ Deptartment of School Buildings, The Education Directorates of Baghdad Karkh, Baghdad, Iraq. \\ ${ }^{2}$ Deptartment of Civil Engineering, University of Baghdad, Baghdad, Iraq.

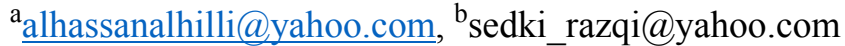

\begin{abstract}
Changes are a common phenomenon in the construction industry, impacting the project's cost, time, and performance. The purpose of this work is to a comprehensive review relating to variation order causes. Also, the aim here is to determine variation order causes in the building's construction. More importantly, explore the relationship between these causes. However, the importance of specifying the causes for change orders is the first step in managing variation orders to reduce the harmful effect on a project. The field survey was conducted for several institutions such as health (Karkh's health), higher education (University of Baghdad and University of Kufa). As a result, a field visit was made to the project sites. They were then, Conducting interviews with the resident engineer, the consultant, and the contractor. A developer tool called cause (variation orders) breakdown structure (CBS) included 12 causes at the first level, including 103 sub-causes. There is a relationship between the variation orders causes, which is evident in the third level. The study recommends adopting (CBS) a comprehensive reference for variation order causes in projects due to facilitating their management processes. Future research could examine the relative importance of variation order causes, in addition to using a fuzzy cognitive map to find the extent of each cause's influence on the other.
\end{abstract}

Keywords: Variation orders; cause (variation orders) breakdown structure (CBS); field survey.

\section{Introduction}

The construction activity is complicated and conventionally fragmented; hence, it is nearly impossible to have a project closed without variations to an initial plan [1]. In other words, it indicates that it is unusual to deliver a project without any difference through its lifecycle [2]. Most contracts must involve terms for permissible variations given the construction project's characteristics [3]. Version orders are not novel to the construction industry, so the variation orders are considered the exclusive lawful means available to variation the contract requirements [4]. The variation orders causes are various, making the variation management challenge difficult for project owners. Therefore, it becomes necessary to review and analyze variation orders' causes to know their impacts on the project [1,5]. The expressions "Variation Order" implore negative feelings toward all concerned in projects. Owners do not wish them because they commonly suppose they are funding for other's errors.

on the other hand, contractors consider that variation orders obstruct work and require paperwork and time [6]. Nevertheless, it is generally that consultants accepted, contractors and owners agree that projects would be satisfactory in the absence of variation orders [7]. Change orders in any project adversely affect the project cost and schedule performance [8]. This is identified as the cumulative impact of change orders [9]. If no approval has arrived from project participants on the variation, it turns into a claim that influences its execution and affects its successful completion [10].

A variation order is one of the few mechanisms that the project manager should contractually have to accommodate unplanned events. It is necessary to have a project manager know the causes behind an unexpected change in the project and respond suitably until the project can be finished successfully [11]. Though, no unique method is available for managing or controlling them adequately. The conventional 
practices involve a portion of the project budget as a reserve for their existence [12]. It was reported in the literature that analysis of change order causes due to (Owner-Contractor-Consultants-Other Causes) $[10,13]$. On the other hand, it is thought analysis (construction-administrative-resources) aspects [14]. According to [15], a hierarchical structure has been created for the change command reasons. It consists of Construction needs and Administrative needs). Variation is "Change or adjustment design, quality, or quantity of the works as illustrated in the contract drawings and defined by or related to in the bill of contract" [16]. Several researchers defined the variation order as:

1) It is work that added to or deleted from the original scope of work of a contract which alters the original contract amount or completion date [17].

2) The deviation experienced in any project from a base contract or work scope mutually agreed at contracting time [18].

3) It is written agreement between the contracting parties that represent an addition, deletion, or revision to the contract documents, identifies the change in price and time and describes the nature of the work involved [19].

4) The formal document that is used to modify the original contractual agreement provided to the contractor by the client or the client's representative and becomes part of the project's documents [20].

5) Legal documents that adapt to any additional work in a contract that was not included in the original contract [21].

6) Any change in the works where a change order is issued in respect thereof or approved as a change under the provisions of (Article Thirteen) [22]. The definition of variation orders will be given as an order issued by the contracting party (Owner) to make a variation in quantity, quality, and scope of work or any component of it. Variation orders deal with unexpected circumstances or, in the case of engineering assessment, to procedure an increase or decrease in quantities or delete or partial addition to working if there does an essential need for variation. Furthermore, the owner has the authority to issue a variation order. Also, the contractor is directed to implement it. This paper will focus on a comprehensive review relating to the variation order causes. Also, this study aimed to determine the variation order causes in a building's construction. More importantly, Explore the relationship between these causes.

\section{Previous Studies}

Alnuaimi et al. [12] examined changes in Oman's public projects by studying changes causes, analyzing changes causes influences on the project, recognizing the beneficial parties, proposing solutions to relevant obstacles, and finding the owner's extra works and design adjustments were the most critical factors variation orders causing. Pourrostam et al. [23] studied describing and assessing the causes and influences of variation orders and methods of variation orders control on construction projects in Iran. Their study revealed the contractor's financial challenges, preceding construction delays by contractors working on various projects also the speedup of work are critical agents responsible for variation orders. Also, delay in completion schedule and extra income for a contractor is listed high by the respondents. Determining policies of variation orders control on building construction. Ismail et al. [24] argued the causes and examined change orders' effects on Iran's roadway construction projects. Results showed the critical factors causing variation orders in the roadway: variation of scope or plans by owner, omissions and errors in design, contractor's financial challenges, and differing site conditions. Time and cost factors established consequences of variation orders in construction projects. Shrestha et al. [8] conducted a statistically analyzing the number of change orders in new and modernization construction projects. The correlation analysis of new projects variation order metrics with contract award cost extension and whole cost growth explained no statistically significant correlation between these variables at $\alpha$ equal to 0.05 . The absence of correlation of variation order metrics with award cost growth refutes the assumption that 
contractors attempt to compensate for their low bid price by creating more change orders throughout construction projects.

Alaryan et al. [25] studied the variation orders in Kuwaiti construction projects by conducting a survey and identifying the major variation orders causes and their influences on projects and controls. Indicated results that the owner is the party charged with causing variation. Furthermore, it identified that the first cause is a variation of plans through the owner. In other ways, the first impact on the project was an increment in the cost. Mohammed [13] identified the most important variation orders causes in various construction sectors in Erbil and their influences on the projects to manage them and suggested the resolutions that can reduce them through control measures. She found the owner and consultant were capable parties causing variations. Also; the most influential of change orders causes in projects were variation in the bill of quantities, change of plans or schedule by the owner, poor contractor background, poor consultant's knowledge about the availability of equipment or materials, omissions design, and faults. Assbeihat et al. [26] found that causes variation orders to include the extended waiting time to get approval on designs, the variation of schedule by the owner, design complexity, absence of contractor's engagement in design, obstructions in securing a site, site safety considerations, and equipment or materials scarce. Senouci et al. [27] recognized of causes and influences of variation orders and developed a structure for appraising the variation orders causes. Eltahir et al. [6] distinguished significant ten agents that cause change orders in the Sudani building project. The variation orders cause and their effect on the Iraqi construction projects, then interpreted the causes using data mining techniques [28,29]. More of the previous studies have examined the variation orders causes as independent causes. A variation in construction projects usually merges various Interconnected causes instead of a different cause.

\section{Methodology}

In this study, the methodology can be shown in Figure 1. This study used different data collection methods such as literature reviewed and field survey. The methodology was achieved in several steps. Firstly, the literature on change orders was reviewed by scientific journals, documents, and books. Also, reviewed 120 scientific papers. Secondly, the field survey was conducted for several institutions such as health (Karkh's health), higher education (University of Baghdad and University of Kufa). As a result, field visits were done to the project sites. Interviews Conducted with the resident engineer, the consultant, and the contractor. Thirdly, survey data were collected from previously implemented projects by studying the files and documenting change orders, their costs, and their impact on the project.

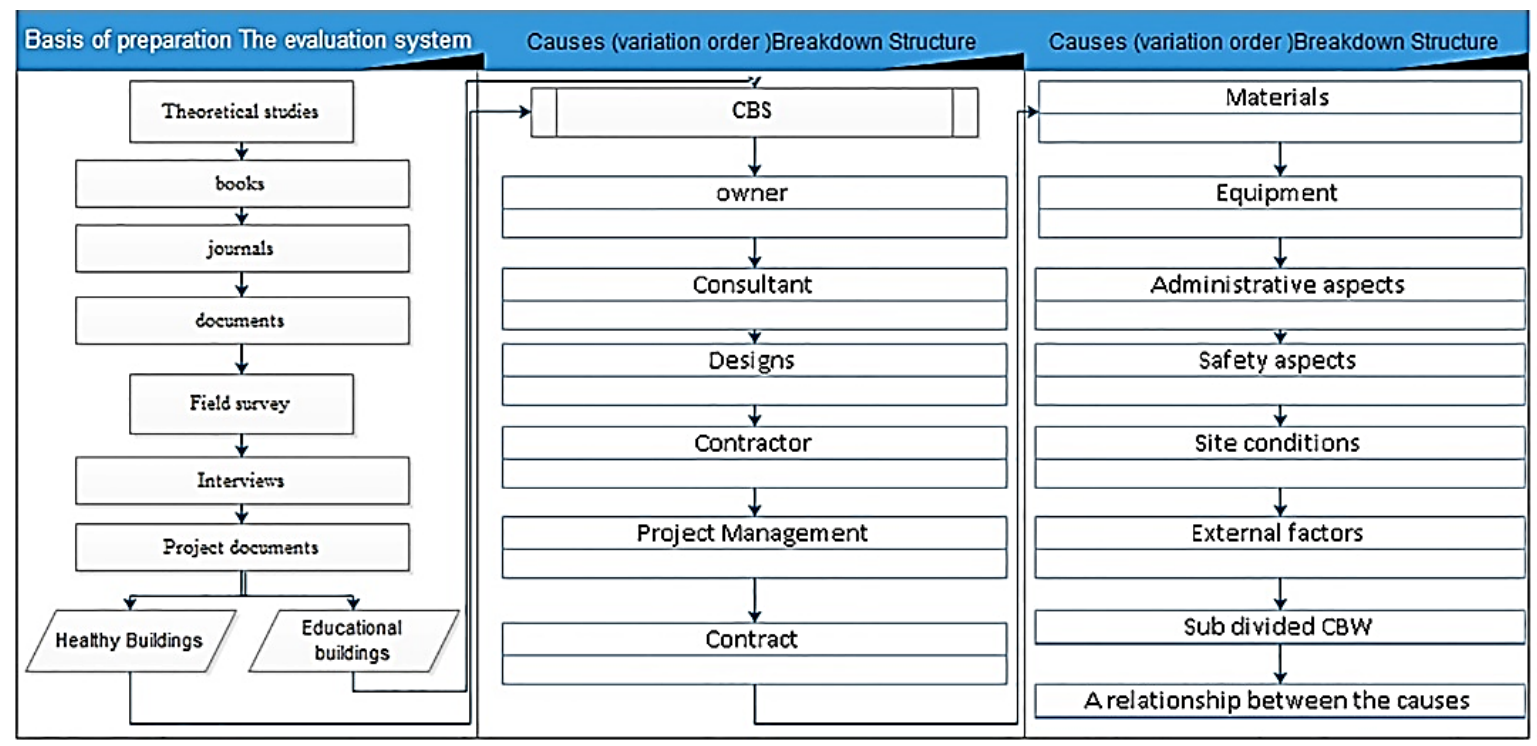

Figure 1. Flow chart of the methodology. 
Finally, survey data included eleven case studies divided into three groups educational and health buildings. The first group consisting of projects (A1, A2, A3, A4, and A5), respectively, dealt with buildings in university Al Kufa while the second group included projects (B1, B2, and B3), sequentially, dealt with buildings in Karkh's health whereas the third group involved projects (D1, D2, and D3), respectively, dealt with buildings in University of Baghdad. The data are presented in Table 1. However, according to our data, the change orders were analyzed to extract the causes for them using cause (variation orders) Breakdown Structure (CBS) by Primavera software (P6). Where the causes were divided into two levels (C), (C.m), (C.m.n), respectively, where $(m=1,2 \ldots, 12),(n=1,2, . ., n) .$.

\section{Results}

It is apparent from Table 1 Health and educational projects and changes order amounts (Quantities Increase-Decrease quantities -Delete quantities - Create a task). Positive and negative change orders can be calculated from the equation (Eq 1, Eq 2). Frequently, the proposed by the researcher as follows:

$$
\begin{aligned}
& \text { Change orders }(+)=\frac{(\text { quantities increase }+ \text { create a task })}{\text { contract price }} \times 100 \\
& \text { Change orders }(-)=\frac{(\text { Decrease quantities }+ \text { Delete quantities })}{\text { contract price }} \times 100
\end{aligned}
$$

The result now provides evidence to projects (A1-A5) Change orders (+) and Change orders (-) Equations (Eq. 1 and Eq. 2). A small amount due to the change orders is few in contrast to other projects. The data in Tables 2 to 4 indicate a Hierarchical structure similar to the work breakdown structure is called cause (variation orders) Breakdown Structure (CBS). It is known as a tool representing the hierarchical structure of change order causes, and it is described from the first level to the third level (C, $\mathrm{C} 1$, and $\mathrm{C} 2$ ).

\begin{tabular}{|c|c|c|c|c|c|c|c|c|}
\hline Code & Project & $\begin{array}{c}\text { Contrac } \\
\text { price } \\
\times 10^{6} \mathrm{IQD}\end{array}$ & $\begin{array}{c}\text { Change } \\
\text { orders } \\
(+) \\
\% \\
\end{array}$ & $\begin{array}{c}\text { Change } \\
\text { orders } \\
(-) \\
\% \\
\end{array}$ & $\begin{array}{c}\text { Quantities } \\
\text { increase } \\
\text { price } \times 10^{6} \\
\text { IQD }\end{array}$ & $\begin{array}{c}\text { Decrease } \\
\text { quantities } \\
\text { price } \times 10^{6} \\
\text { IQD }\end{array}$ & $\begin{array}{c}\text { Delete } \\
\text { quantities } \\
\text { price } \times 10^{6} \\
\text { IQD }\end{array}$ & $\begin{array}{c}\text { Create } \\
\text { clauses } \\
\text { price } \times 10^{6} \\
\text { IQD }\end{array}$ \\
\hline A1 & Internal departments (female) & 1900 & 1.0 & 0.0 & 19.3 & 0 & 0 & 0 \\
\hline A2 & Dean of the Faculty of Arts & 1255 & 1.5 & 1.8 & 14 & 0 & 22.5 & 4.5 \\
\hline A3 & Dean of the College of Medicine & 1920 & 0.3 & 0.0 & 4.55 & 0 & 0 & 1.5 \\
\hline A4 & Internal departments (male) & 1855 & 1.1 & 0.0 & 6 & 0 & 0 & 13.6 \\
\hline A5 & College of Science Part 9 A and B. & 3325 & 3.5 & 0.0 & 0 & 0 & 0 & 118 \\
\hline B1 & $\begin{array}{l}\text { Construct house resident doctors at } \\
\text { Yarmouk Teaching Hospital }\end{array}$ & 1716 & 25.7 & 31.6 & 250.35 & 100.8 & 442.102 & 190.99 \\
\hline B2 & $\begin{array}{l}\text { Demolition and construction of a } \\
\text { health center }\end{array}$ & 899.66 & 18.6 & 13.9 & 25.4 & 75.04 & 50.23 & 141.77 \\
\hline B3 & $\begin{array}{l}\text { Construct of a coordinated } \\
\text { Tuberculosis }\end{array}$ & 828.696 & 11.5 & 5.8 & 40.179 & 42.996 & 5.12 & 55.2 \\
\hline D1 & $\begin{array}{l}\text { Institute of a building genetic } \\
\text { engineering }\end{array}$ & 7865 & 9.8 & 3.0 & 539.993 & 233.431 & 0 & 228.01 \\
\hline D2 & Construction of the College of Law & 7865 & 11.0 & 4.6 & 667.567 & 362 & 0 & 195 \\
\hline D3 & $\begin{array}{l}\text { Construction of the College of } \\
\text { Science for Girls }\end{array}$ & 7733.66 & 6.4 & 2.1 & 402.467 & 163.289 & 0 & 93 \\
\hline
\end{tabular}

Table 1. The data of field survey. 
Table 2. Variation orders analysis of CBS-C.1, C.2, and C.3.

\begin{tabular}{|c|c|c|}
\hline CBS Code & CBS Name & \\
\hline $\mathbf{C}$ & Causes change orders & Reference \\
\hline C.1 & Owner & \\
\hline C.1.1 & Schedule change & [30] \\
\hline C.1.2 & Scope change & [30] \\
\hline C.1.3 & Change in the Action Plan & [30] \\
\hline C.1.4 & Decision making is slow and complicated & [30] \\
\hline C.1.5 & The delay in the payment of the contracting parties & [30] \\
\hline C.1.6 & Difficult financial situation & [30] \\
\hline C.1.7 & The character of the owner is strict and inflexible & {$[10]$} \\
\hline C.1.8 & The goals of the project are incomplete & Field survey \\
\hline C.1.9 & Owner requirements incomplete & Field survey \\
\hline C.1.10 & Weakness in reviewing project documentation & Field survey \\
\hline C.1.11 & Owner requirements unclear & {$[31]$} \\
\hline C.1.12 & Job change in a project structure & Field survey \\
\hline C.1.13 & Weakness in project management & Field survey \\
\hline C.1.14 & Lack of owner experience & Field survey \\
\hline C.1.15 & Not to hand over the right site time for the contractor & Field survey \\
\hline C.1.16 & Change in the sequence of implementation & Field survey \\
\hline C.1.17 & Desire to start early in the project & {$[10]$} \\
\hline C.1.18 & Determine the time of activities is not suitable & Field survey \\
\hline C.1.19 & Change the decision-making authority frequently & Field survey \\
\hline C.2 & Consultant & \\
\hline C.2.1 & Lack of coordination between different specialization designers & [30] \\
\hline C.2.2 & $\begin{array}{l}\text { Lack of consultant experience } \\
\end{array}$ & [10] \\
\hline C.2.3 & The consultant was late in approving & {$[30]$} \\
\hline C.2.4 & Delayed in responding to problems & Field survey \\
\hline C.2.5 & Inflexible consultant personality & {$[30]$} \\
\hline C. 2.6 & The weakness of supervision as a representative of the owner & [30] \\
\hline C.2.7 & Lack of knowledge of the presence of materials in the market & {$[10]$} \\
\hline C.2.8 & Weakness in preparing a bill of quantities & Field survey \\
\hline C.2.9 & Weak consultant guess & {$[10]$} \\
\hline C. 2.10 & Inadequate identification of the logical relationship between the activities & Field survey \\
\hline C.3 & Designs & \\
\hline C.3.1 & Lack of clarity designs and technical specifications & [13] \\
\hline C.3.2 & Errors and omissions in designs & [30] \\
\hline C.3.3 & The level of complexity of designs & {$[30]$} \\
\hline C.3.4 & Insufficient design details to work & Field survey \\
\hline C.3.5 & Design inconsistency with regulations & Field survey \\
\hline C.3.6 & Designs not meeting the owner's requirements & {$[10]$} \\
\hline C.3.7 & The workshop layout is insufficient & Field survey \\
\hline C.3.8 & Errors and omissions in calculating quantities & {$[15]$} \\
\hline C.3.9 & Value engineering & [31] \\
\hline C.3.10 & Delay in reviewing designs (ambiguity in designs) & Field survey \\
\hline C.3.11 & Citation specification is not suitable for the project & {$[15]$} \\
\hline
\end{tabular}


Table 3. Variation orders analysis of CBS-C.4, C.5, C.5, and C.6.

\begin{tabular}{|c|c|c|}
\hline CBS Code & CBS Name & Reference \\
\hline C.4 & Contractor & \\
\hline C.4.1 & Weak contractor management and supervision & [30] \\
\hline C.4.2 & Poor contractor planning and scheduling & [30] \\
\hline C.4.3 & Bad contractor financial position & {$[30]$} \\
\hline C.4.4 & The weakness of the contractor's work team & Field survey \\
\hline C.4.5 & Secondary contractors are ineffective & Field survey \\
\hline C.4.6 & Desire to make profits & {$[30]$} \\
\hline C.4.7 & Inadequate communication within the project parties & [30] \\
\hline C.4.8 & Delay in paying the dues of secondary contractors, suppliers & {$[30]$} \\
\hline C.4.9 & Delayed supply of resources & Field survey \\
\hline C.4.10 & Inadequate supply of resources and equipment to the site & Field survey \\
\hline C.4.11 & The complexity of designs by the contractor & [13] \\
\hline C.4.12 & Failure to coordinate with the employer supervising authority & {$[10]$} \\
\hline C.4.13 & Lack of productivity of the contractor's work team & [32] \\
\hline C.5 & Project management & \\
\hline C.5.1 & Lack of coordination between the parties & [13] \\
\hline C.5.2 & Poor communication & Field survey \\
\hline C.5.3 & Weak data available & [13] \\
\hline C.5.4 & The work progress schedule is unclear & Field survey \\
\hline C.5.5 & A change in project regulations & Field survey \\
\hline C.5.6 & Poor risk management & Field survey \\
\hline C.5.7 & Occupational safety procedures & Field survey \\
\hline C.5.8 & Weak field experience of the Resident Engineer & Field survey \\
\hline C.5.9 & Adhere to the routine procedures for approvals for the conduct of work & Field survey \\
\hline C.6 & Contract & \\
\hline C.6.1 & Conflict in the contract documents & [15] \\
\hline C.6.2 & Contract documents are unclear & {$[10]$} \\
\hline C.6.3 & The work scope is unclear within the contract & Field survey \\
\hline C.6.4 & Lack of contract documents & {$[10]$} \\
\hline C.6.5 & Poor contract preparation & Field survey \\
\hline C.6.6 & Inaccurate review of the contract & Field survey \\
\hline C.6.7 & The contract does not include all aspects of the project & Field survey \\
\hline C.6.8 & The contract is not appropriate, such as this type of work & Field survey \\
\hline C.6.9 & Terms of the contract contain unclear clauses & {$[15]$} \\
\hline C.6.10 & Corruption and suspicions in concluding contracts & {$[10]$} \\
\hline C.6.11 & Conducting the contract before the completion of the contract documents & Field survey \\
\hline C.6.12 & insufficient site investigation & [15] \\
\hline C.7 & Materials & \\
\hline C.7.1 & Unavailability of the required materials & {$[32]$} \\
\hline C.7.2 & Material failure in laboratory testing & Field survey \\
\hline C.7.3 & Delay in arrival of materials & Field survey \\
\hline C.7.4 & Change material specifications to benefit the project & Field survey \\
\hline C.7.5 & Change materials to achieve the exact specifications and lower prices & Field survey \\
\hline C.7.6 & Technical necessity & {$[10]$} \\
\hline C.7.7 & Constructive necessity & Field survey \\
\hline C.7.8 & Poor transportation of materials in the project & {$[32]$} \\
\hline C.7.9 & Poor management of materials on site & [32] \\
\hline
\end{tabular}


Table 4. Variation orders analysis of CBS-C.8, C.9, C.10, C.11, and C.12.

\begin{tabular}{|c|c|c|}
\hline C.8 & Equipment & \\
\hline C.8.1 & Insufficient equipment and tools & Field survey \\
\hline C.8.2 & Use obsolete equipment and tools & Field survey \\
\hline C.8.3 & Failure of equipment to perform its work & {$[31]$} \\
\hline C.8.4 & The poor performance of the equipment & [32] \\
\hline C.8.5 & Equipment break down when performing work & [32] \\
\hline C.9 & Administrative aspects & \\
\hline C.9.1 & The lack of understanding between the project parties & [32] \\
\hline C.9.2 & Failure to provide the revised designs with the specified time & [32] \\
\hline C.9.3 & Poor communication between workers and management & [32] \\
\hline C.9.4 & Poor Administrative & Field survey \\
\hline C.9.5 & Weakness in decision-making & {$[32]$} \\
\hline C.9.6 & Municipal regulations and urban planning & Field survey \\
\hline C.9.7 & Review the insurance regulations and the environmental protection & {$[15]$} \\
\hline C.9.8 & Fire fighting regulations and waste management regulations & [33] \\
\hline C.9.9 & Regulations for Archeology, roads, and electricity & {$[15]$} \\
\hline C.10 & Safety aspects & \\
\hline C. 10.1 & Safety procedures and policies not sufficient on-site & [10] \\
\hline C. 10.2 & Site safety considerations & [15] \\
\hline C.11 & Site conditions & \\
\hline C.11.1 & The nature of the site & {$[15]$} \\
\hline C.11.2 & Transgressors & Field survey \\
\hline C.11.3 & the site situation & {$[13]$} \\
\hline C.11.4 & Uncertainty problems of the land site & [30] \\
\hline C.11.5 & Available workspace & Field survey \\
\hline C.12 & External factors & \\
\hline C.12.1 & Environmental conditions & [32] \\
\hline C.12.2 & Economic conditions & [10] \\
\hline C. 12.3 & Political legislation & [10] \\
\hline C. 12.4 & Third-party actions & {$[10]$} \\
\hline C. 12.5 & Force Majeure & Field survey \\
\hline C.12.6 & Emergency conditions & Field survey \\
\hline C.12.7 & Accidents & {$[13]$} \\
\hline C.12.8 & Damage to the interests of people outside of the parties to the project & Field survey \\
\hline C.12.9 & Political conditions & {$[15]$} \\
\hline C.12.10 & Cultural conditions & Field survey \\
\hline
\end{tabular}

\section{Conclusions}

This study's findings can be understood as more Change orders (-) increases, Change orders (+) leads to a negative impact on the project. From this study, it was determined to change order causes in the building construction. Nevertheless, we found a developer tool called cause (variation orders) Breakdown Structure. (CBS) As it included 12 causes at the first level, and it includes 103 sub-causes. Results provide a basis for a relationship between the causes for the variation orders. This is evident in the third level. For example, when changing schedules (c.1.1) by the owner leads to a change in scope (C.1.2), which leads to the lack of sufficient labor for a contractor (C.4.13). In addition to the consultant not understanding the owner's requirements (C.2.11). As a result, it leads to change order. However, previous studies dealt with the factors causing change orders as independent factors without addressing the mutual effect. The study recommends adopting. (CBS) as a comprehensive guide for change orders causes in construction projects due to facilitating their management processes. Future research could examine the relative importance of variation orders causes. Using a fuzzy cognitive map to find the extent of each cause's influence on the other, which management of change orders is facilitated. 


\section{Acknowledgment}

The authors would like to acknowledge the University of Baghdad, University of Kufa, and Baghdad Health Department to achieve this study.

\section{References}

[1] Oyewobi, L.O., Jimoh, R., Ganiyu, B.O. and Shittu, A.A., 2016. Analysis of causes and impact of variation order on educational building projects. Journal of Facilities Management.

[2] Alsuliman, J., Bowles, G., Chen, Z. and Smith, S.D., 2012. Current practice of variation order management in the Saudi construction industry. Association of Researchers in Construction Management, pp.1-10.

[3] Sunday, O.A., 2010, September. Impact of variation orders on public construction projects. In Proceedings of the 26th Annual ARCOM Conference (pp. 6-8). Leeds: Association of Researchers in Construction Management.

[4] Hasan, B., Jrad, F. and Ahmed, S., 2010. Study the causes of formal change orders and analyze their impact on building projects: the case of Syria.

[5] Ibn-Homaid, N.T., Eldosouky, A.I. and Al-Ghamdi, M.A., 2011. Change orders in Saudi linear construction projects. emirates Journal for engineering Research, 16(1), pp.33-42.

[6] Mohammed, E.E., Mohammed, S.Y. and Hassan, A.S., 2017. Factors causing variation orders in building projects in Khartoum State-Sudan. International Journal of Engineering Sciences \& Research Technology, 6(11), pp.117-129.

[7] Arain, F.M. and Low, S.P., 2005. The nature and frequency of occurence of variation orders for educational building projects in Singapore. International journal of construction management, 5(2), pp.79-91.

[8] Shrestha, P.P. and KK, Z.H.S., 2013. An analysis of change orders in public school projects. In Proceedings of the CSCE 2013 on 4th construction specialty conference.

[9] Zhang, X. and Tariq, S., 2020. Failure mechanisms in international water PPP projects: A public sector perspective. Journal of Construction Engineering and Management, 146(6), p.04020055.

[10] Wali, K.I. and Saber, N.I., 2019. An Analysis of Causes and Factors Affecting Change Orders Occurrence in Construction Projects in Iraq. Zanco Journal of Pure and Applied Sciences, 31(6), pp.1-12.

[11] Msallam, M., Abojaradeh, M., Jrew, B. and Zaki, I., 2015. Controlling of variation orders in highway projects in Jordan. Journal of Engineering and Architecture, 3(2), pp.95-104.

[12] Alnuaimi, A.S., Taha, R.A., Al Mohsin, M. and Al-Harthi, A.S., 2010. Causes, effects, benefits, and remedies of change orders on public construction projects in Oman. Journal of construction engineering and management, 136(5), pp.615-622.

[13] Mohammed, A.J., 2016. A Study For The Causes Of Variation Orders In Different Sectors Of Construction Projects In Erbil Governorate From The Point Of View Of The Involved Parties. Journal of Engineering and Sustainable Development, 20(5).

[14] Desyardi, H., Latief, Y. and Soepandji, B.S., 2019, April. Guidelines for effective Variation Order determination strategy. In IOP Conference Series: Earth and Environmental Science (Vol. 258, No. 1, p. 012030). IOP Publishing.

[15] Hsieh, T.Y., Lu, S.T. and Wu, C.H., 2004. Statistical analysis of causes for change orders in metropolitan public works. International Journal of Project Management, 22(8), pp.679-686.

[16] Mohammad, N., Ani, A.C., Rakmat, R.A.O.K. and Yusof, M.A., 2010. Investigation on the causes of variation orders in the construction of building project-a study in the state of Selangor, Malaysia. Journal of Building Performance, 1(1).

[17] Wan Abdullah Zawawi, N.A., Nik Azman, N.F.I. and Shamsul Kamar, M.S., 2010. Sustainable construction practice: A review of Change Orders (CO) in Construction Projects. 
[18] Keane, P., Sertyesilisik, B. and Ross, A.D., 2010. Variations and change orders on construction projects. Journal of legal affairs and dispute resolution in engineering and construction, 2(2), pp.8996.

[19] Memon, A.H., Rahman, I.A. and Hasan, M.F.A., 2014. Significant causes and effects of variation orders in construction projects. Research Journal of Applied Sciences, Engineering and Technology, 7(21), pp.4494-4502.

[20] Halwatura, R.U. and Ranasinghe, N.P.N.P., 2013. Causes of variation orders in road construction projects in Sri Lanka. International Scholarly Research Notices, 2013.

[21] Kermanshachi, S. and Rouhanizadeh, B., 2019, June. Sensitivity Analysis of Construction Schedule Performance Due to Increased Change Orders and Decreased Labor Productivity. In 7th CSCE International Construction Specialty Conference (ICSC) (pp. 12-15).

[22] Standard Bid Documents. 2016. Standard bid documents for general competitive tenders for the general of executing general works. Ministry of Planning, Iraq.

[23] Pourrostam, T., Ismail, A. and Mansournejad, M., 2011. Identification and evaluation of causes and effects of change orders in building construction projects. In Applied Mechanics and Materials (Vol. 94, pp. 2261-2264). Trans Tech Publications Ltd.

[24] Ismail, A., Pourrostam, T., Soleymanzadeh, A. and Ghouyounchizad, M., 2012. Factors causing variation orders and their effects in roadway construction projects. Research Journal of Applied Sciences, Engineering and Technology, 4(23), pp.4969-4972.

[25] Alaryan, A., Emadelbeltagi, A.E. and Dawood, M., 2014. Causes and effects of change orders on construction projects in Kuwait. International Journal of Engineering Research and Applications, 4(7), pp.1-8.

[26] Assbeihat, J.M. and Sweis, G.J., 2015. Factors affecting change orders in public construction projects. International Journal of Applied, 5(6).

[27] Senouci, A., Alsarraj, A., Gunduz, M. and Eldin, N., 2017. Analysis of change orders in Qatari construction projects. International Journal of Construction Management, 17(4), pp.280-292.

[28] Naji, H.I., Hatem, W.A. and Maula, B.H., 2018. Change Orders in Iraqi Construction Projects. The Open Civil Engineering Journal, 12(1).

[29] Mohammad, N. and Hamzah, Z., 2019. A review of causes of variation order in the construction of terrace housing projects in Malaysia. In MATEC Web of Conferences (Vol. 277, p. 03013). EDP Sciences.

[30] Jarkas, A.M. and Mubarak, S.A., 2016. Causes of construction change orders in Qatar: contractors' perspective. International Journal of Project Organisation and Management, 8(3), pp.275-299.

[31] Gunduz, M. and Khan, O.H., 2018. Effective Framework for Change Order Management Using Analytical Hierarchy Process (AHP). Gazi University Journal of Science, 31(4), pp.1079-1091.

[32] Tiware, M.V. and Kulkarni, S.S., 2013. Root cause analysis of variations in construction tasks and developing effective strategies to reduce variations. International Journal of Scientific Engineering and Research, 4(9), pp.51-58.

[33] Perera, B.A.K.S., Ekanayake, B.J., Jayalath, C. and Jayathilaka, G.R.H., 2019. A study on variationspecific disputes that arise in road projects in Sri Lanka: a qualitative approach. International Journal of Construction Management, pp.1-11. 